\title{
Predation of Boana boans (Anura, Hylidae) by an opportunistic frugivorous primate
}

\author{
Thiago CAVALCANTE ${ }^{1 *} \mathbb{\bullet}$, Pedro Ivo SIMÓES², Italo MOURTHE \\ 1 Instituto Nacional de Pesquisas da Amazônia - INPA, Grupo de Pesquisa de Mamíferos Amazônicos, Av. André Araújo 2936, 69067-375 Manaus, Amazonas, Brasil \\ 2 Universidade Federal de Pernambuco - UFPE, Centro de Ciências Biológicas, Departamento de Zoologia, Avenida Prof. Moraes Rego $1235,50670-420$ Recife, \\ Pernambuco, Brasil \\ 3 Universidade Federal do Pará - UFPA, Faculdade de Ciências Biológicas, Laboratório de Ecologia e Programa de Pós-graduação em Biodiversidade e Conservação, \\ Rua José Porfírio 2515, 68.372-040 Altamira, Pará, Brasil \\ * Corresponding author: thiagocav.ferreira@gmail.com; D https://orcid.org/0000-0001-5357-9659
}

\section{ABSTRACT}

Although relatively common among omnivorous primates, anurophagy is still poorly documented in frugivorous species. Here we report the predation of a giant gladiator treefrog (Boana boans) by a large arboreal frugivore, the gray woolly monkey (Lagothrix lagotricha cana). The predation event occurred in a stretch of riparian forest located in a fragmented region in Cacoal, Rondônia state, in southwestern Brazilian Amazonia. Anurans can be a profitable, non-contested, and relatively easily acquired alternative resource for gray woolly monkeys, helping to fulfill their demand for protein, especially in periods of fruit scarcity. This new record broadens the knowledge on the natural history and predators of the giant gladiator frog.

KEYWORDS: Amazonia, anuran predation, anurophagy, diet, Lagothrix lagotricha cana

\section{Predação de Boana boans (Anura, Hylidae) por um primata frugívoro oportunista}

\section{RESUMO}

Embora relativamente comum entre primatas onívoros, a anurofagia ainda é pouco documentada entre espécies frugívoras. Relatamos a predação de um sapo-canoeiro (Boana boans) por um primata frugívoro de grande porte, o macaco-barrigudo (Lagothrix lagotricha cana). O evento de predação ocorreu em um fragmento de floresta ripária localizado em Cacoal, Rondônia, no sudoeste da Amazônia brasileira. Anuros podem ser um recurso alternativo vantajoso, não contestado, e de aquisição relativamente fácil para macacos-barrigudos, ajudando a suprir sua demanda por proteína, especialmente em períodos de escassez de frutos. Nosso registro expande o conhecimento sobre a história natural e os predadores do sapo-canoeiro.

PALAVRAS-CHAVE: Amazônia, anurofagia, dieta, Lagothrix lagotricha cana, predação de anuros

Anurans are commonly preyed by a wide spectrum of vertebrates, including birds, reptiles, and mammals (Toledo et al. 2007). Even though snakes are one of their main predators (Toledo et al. 2007), the importance of primate predation as a selective pressure for arboreal frogs remains unclear. Additionally, the proportion of the diets composed by anurans remains largely unknown for most primates, since primate predation of anurans is rarely observed, and poorly reported. Most reports available so far documented predation by omnivorous primates, such as small callitrichids (Heymann et al. 2000; Passamani and Rylands 2000; Canale and Lingnau 2003; Cicchi et al. 2010; Beltrão-Mendes et al. 2016) and cebids (Izawa 1978; Freese and Oppenheimer 1981). However, anurophagy remains particularly under-reported in opportunistic frugivorous primates. Here, we report for the first time the predation of a giant gladiator treefrog (Boana boans Linnaeus, 1758) by a large arboreal atelin, the gray woolly monkey (Lagothrix lagotricha cana É. Geoffroy, 1812).

The giant gladiator treefrog is a nocturnal anuran found throughout the tropical forests of the Amazon basin and cis-Andean northern South America (Barrio-Amorós 2001; Lima et al. 2006; Frost 2019). Although widely distributed and relatively abundant throughout Amazonia, little is known about the predators of this large treefrog (snout-vent length = 86.5-128 mm: Lima et al. 2006; Ovalle-Pacheco et al. 2019). To our knowledge, the only reports available for this species so far are a confirmed predation by the Neotropical parrot snake (Leptophis ahaetulla: Gama and Costa-Campos 2014), and attempted predation by the South American water snake (Helicops angulatus: Rocha and López-Baucells 2014).

The gray woolly monkey is a highly arboreal frugivore and one of the largest primates of the Amazonian forests 
of Brazil, Peru and Bolivia (Fooden 1963; Peres 1994). Fruit accounts for more than $80 \%$ of the year-round diet of this primate (Peres 1994). Additionally, this large atelid also consumes young leaves, flowers, and exudates, while arthropods represent only $0.1 \%$ of its overall diet (Peres 1994). In a study carried out in the dry season, in highly altered and small fragments, the frequency of prey consumption increased to $7 \%$ (Cavalcante 2018). There is no information on vertebrate consumption by Lagothrix l. cana, though other woolly monkeys are known to consume frogs (e.g., Lagothrix lagotricha, Stevenson et al. 1994; Lagothrix l. poeppigii, Di Fiore 2004). However, no anuran prey species was formerly identified in these studies.

We observed the predation event while collecting data on the feeding ecology on a group of 20+ habituated woolly monkeys in a riparian forest located in Cacoal $\left(11.3191^{\circ} \mathrm{S}\right.$, $\left.61.4321^{\circ} \mathrm{W}\right)$, Rondônia state, in the southwestern Brazilian Amazonia (Cavalcante 2018). The studied stretch of forest included the riparian vegetation along a small stream within a 120 ha mosaic of fragmented forest. The main vegetation in the region is classified as ombrophilous open forest (Oliveira 2002), within the Amazonian domain (see Cavalcante 2018 for a detailed description of the studied area). The climate is tropical humid (Koppën AW), with a mean temperature of $27^{\circ} \mathrm{C}$, and precipitation ranging from 1600 to $2400 \mathrm{~mm} /$ year (rainy season: October-May) (SEDAM 2012). Woolly monkeys were followed from dawn until dusk on a regular daily basis for three to six days per month, between March and October, 2017, resulting in 617 observation hours.

We did not collect prey remains, but took photographs that were deposited in the Amphibian Collection of the Museu de Ciências e Tecnologia of Pontifícia Universidade Católica do Rio Grande do Sul (MCP 13923). Species determination was possible through diagnostic characters evident in these photographs and in our field notes. The specimen had longitudinal length from vent to edge of severed head of approximately $100 \mathrm{~mm}$. The frog fauna of the region has been fairly well studied (Bernarde et al. 1999; Bernarde 2007; Turci and Bernarde 2012). The only treefrogs as large as the one reported here are Boana boans, B. lanciformis, Phyllomedusa vaillanti, P. tarsius, Trachycephalus venulosus, T. resinifictryx and Osteocephalus taurinus. Boana lanciformis and Phyllomedusa spp. have white femoral bones, and Phyllomedusa spp. have solid green dorsal thigh surfaces. Both species of Trachycephalus have extremely large granules scattered dorsally. Osteocephalus taurinus has smaller granules scattered on dorsal surfaces of body, thighs and shanks, and irregular transverse dark brown bars on thigh dorsal surfaces. The remains we recorded had green femoral bones, smooth orange-brown skin on the dorsum and hindlimbs, uniformly white to greenish-cream ventral surface and regular transverse faint brown bars on flanks (Figure 1a,b). Therefore, we confidently identified it as Boana boans (Lima et al. 2006).
The predation event occurred at 12:38 h on 2 October 2017. It took place approximately $10 \mathrm{~m}$ from the margin of a small stream. We observed an adult female woolly monkey preying upon an adult Boana boans in the canopy of a tree (Figure 1c), at a height of approximately $10 \mathrm{~m}$. The female handled the prey for more than $10 \mathrm{~min}$. After consuming the head, forelimbs, shanks and feet, the monkey dropped the frog remains on the forest floor (Figure 1a,b). Another adult female was also observed preying upon a treefrog at the same locality at $06: 38 \mathrm{~h}$ on 3 October 2017, but we did not find any remains that would enable species determination.

Vertebrate predation is widespread within the primate radiation (Butynski 1982). Primate prey includes a wide range of animals, varying from birds to reptiles and mammals, with frog predation being particularly common in some taxa (e.g., cebids and marmosets: Izawa 1978; Fedigan 1990; Digby and Barreto 1998). However, the inherent irregularity of these predation events and our hampered view inside forest canopies limit our understanding of the role of frogs in primate diets, particularly among frugivores, such as woolly monkeys.

Anurophagy has already been reported in the diet of woolly monkeys (Stevenson et al. 1994; Di Fiore 2004), but the importance of animal matter in their diets is still poorly understood. Fruits are an important source of water, macronutrients and energy, but are low in protein, and frugivores may have to regulate their ingestion of this essential nitrogenous organic compound (Di Fiore 2003; Milton 2008; Mourthe and Casal 2017). Meat is very high in protein, averaging 22\% dry matter (Aguiar 1996), which is higher than most other food items consumed by primates and other frugivores (Heymann et al. 2000; Mourthe and Casal 2017). Animal matter consumption is an important

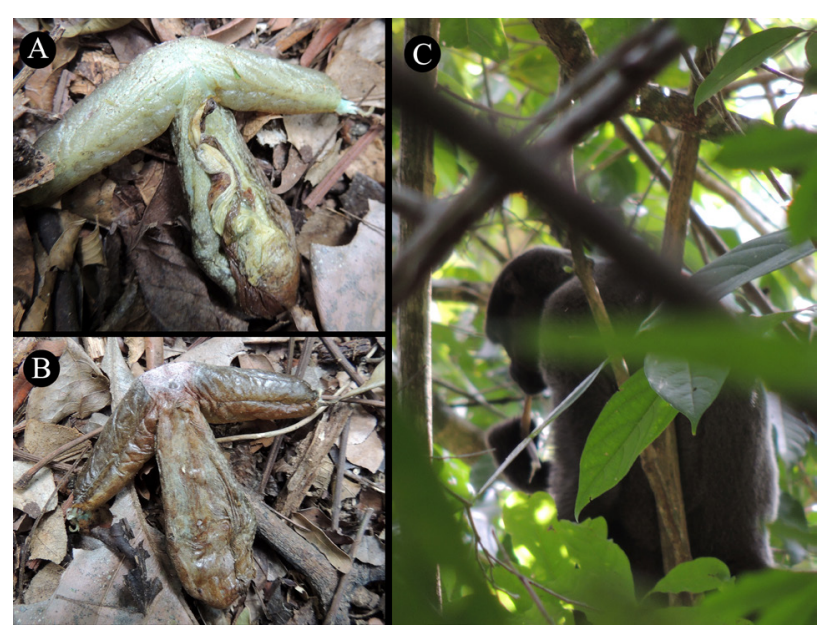

Figure 1. Evidence of Lagothrix lagotricha cana predation on Boana boans in a forest fragment in Cacoal, Rondônia, Brazil. Ventral (A) and dorsal (B) view of the carcass of a B. boans individual after having been dropped by the predator primate, and an adult female L. I. cana consuming an adult B. boans (C). This figure is in color in the electronic version. 
resource for woolly monkeys during periods of fruit scarcity (Stevenson et al. 1994; Di Fiore 2003), and vertebrate prey may be particularly critical during periods of joint shortage of both fruits and invertebrates (Fedigan 1990; Gómez-Posada 2012). Foraging for animal prey can involve some degree of premeditation, persistence, and in some cases, cooperation (Butynski 1982). However, we believe Lagothrix l. cana may prey opportunistically on treefrogs, notably when they find these nocturnal animals while resting diurnally in the canopy (Beltrão-Mendes et al. 2016). Therefore, even considering the apparent unpredictable nature of anuran predation, animal matter can be a profitable, non-contested, and relatively easily acquired alternative resource for gray woolly monkeys that helps to fulfill their demand for protein (Di Fiore 2003).

Predators of the giant gladiator frog are poorly documented and this new record broadens our knowledge about the natural history of the species. Primate predation on anurans clearly deserve more studies (e.g., Digby and Barreto 1998), particularly the importance of anurans in the diet of opportunistic frugivorous primates and whether primate predation can act as a selective force in the evolution of treefrogs. The increasing number of reports of primate-anuran interactions may allow us to investigate broader ecological patterns in the future (e.g., Toledo et al. 2007).

\section{ACKNOWLEDGMENTS}

We thank the landowners that kindly allowed us to collect data in their properties and P. S. Bernarde for providing information on treefrog species occurring in the study area. We also thank the Coordenação de Aperfeiçoamento de Pessoal de Nivel Superior for providing the research fellowships (PNPD/ CAPES) and scholarship.

\section{REFERENCES}

Aguiar, J.P.L. 1996. Table of nutrient composition of Amazonian foods. Acta Amazonica, 26: 121-126.

Barrio-Amorós, C.L. 2001. Hyla Boans (Giant Gladiator Treefrog). Venezuela: Estado Barinas. Herpetological Review, 32: 113-114.

Beltrâo-Mendes, R.; Cavalcante, C.B.; Caldas, F.L.S.; Ferrari, S.F. 2016. Hypsiboas albomarginatus (white-edged treefrog). Predation. Herpetological Review, 47: 110-110.

Bernarde, P.S. 2007. Ambientes e temporada de vocalização da anurofauna no município de Espigão do Oeste, Rondônia, sudoeste da Amazônia-Brasil (Amphibia: Anura). Biota Neotropica, 7: 87-92.

Bernarde, P.S.; Kokubum, M.N.C.; Machado, R.A.; Anjos, L. 1999. Uso de habitats naturais e antrópicos pelos anuros em uma localidade no estado de Rondônia, Brasil (Amphibia: Anura). Acta Amazonica, 29: 555-562.

Butynski, T.M. 1982. Vertebrate predation by primates: a review of hunting patterns and prey. Journal of Human Evolution, 11: 421-430.
Canale, G.; Lingnau, R. 2003. Hyla biobeba (NCN). Predation. Herpetological Review, 34: 136-136.

Cavalcante, T. 2018. Influência da disponibilidade e consumo de frutos no comportamento agonistico e espaçamento interindividual de macacos barrigudos (Lagothrix cana). Master's dissertation, Pontifícia Universidade Católica do Rio Grande do Sul, Brazil. 39p.

Cicchi, P.J.; Jim, J.; Centeno, F.C. 2010. Hypsiboas albomarginatus (white-edged treefrog). Predation. Herpetological Review, 41: 64-64.

Di Fiore, A. 2003. Ranging behavior and foraging ecology of lowland woolly monkeys (Lagothrix lagotricha poeppigii) in Yasuni National Park, Ecuador. American Journal of Primatology, 59: 47-66.

Di Fiore, A. 2004. Diet and feeding ecology of woolly monkeys in a western Amazonian rain forest. International Journal of Primatology, 25: 767-801.

Digby, L.; Barreto, C. 1998. Vertebrate predation in common marmosets. Neotropical Primates, 6: 124-126.

Fedigan, L.M. 1990. Vertebrate predation in Cebus capucinus: meat eating in a neotropical monkey. Folia Primatologica, 54: 196-205.

Fooden, J. 1963. A revision of the woolly monkeys (genus Lagothrix). Journal of Mammalogy, 44: 213-247.

Freese, C.; Oppenheimer, J. 1981. The capuchin monkeys, genus Cebus. In: Coimbra-Filho, A.F.; Mittermeier, R.A. (Eds.). Ecology and behavior of Neotropical primates. Academia Brasileira de Ciencias, Rio de Janeiro, p.331-390.

Frost, D. 2019. Amphibian species of the world: an online reference. Version 6.0. American Museum of Natural History, USA (http:// research.amnh.org/herpetology/amphibia/index.html). Accessed on 8 Dec 2018.

Gama, C.S.; Costa-Campos, C.E. 2014. Hypsiboas boans (giant gladiator treefrog). Predation. Herpetological Review, 45: 680.

Gómez-Posada, C. 2012. Dieta y comportamiento alimentario de un grupo de mico maicero Cebus apella de acuerdo a la variación en la oferta de frutos y artrópodos, en la Amazonía colombiana. Acta Amazonica, 42: 363-372.

Heymann, E.W.; Knogge, C.; Tirado Herrera, E.R. 2000. Vertebrate predation by sympatric tamarins, Saguinus mystax and Saguinus fuscicollis. American Journal of Primatology, 51: 153-158.

Izawa, K. 1978. Frog-eating behavior of wild black-capped capuchin (Cebus apella). Primates, 19: 633-642.

Lima, A.; Magnusson, W.; Menin, M.; Erdtmann, L.; Rodrigues, D.; Keller, C.; Hödl, W. 2006. Guide to the Frogs of Adolpho Ducke Reserve, Central Amazonia. Áttema Design Editorial, Manaus, 168p.

Milton, K. 2008. Macronutrient patterns of 19 species of Panamanian fruits from Barro Colorado Island. Neotropical Primates, 15: 1-8.

Mourthe, I.; Casal, A.C. 2017. Chelonoids carbonaria (red-footed tortoise). Scavenging behavior. Herpetological Review, 48: 422423.

Oliveira, O.A. 2002. Geografia de Rondônia: espaço e produção. Dinâmica Editora, Porto Velho, 160p. 
Ovalle-Pacheco, A.; Camacho-Rozo, C.; Arroyo, S. 2019. Amphybians from Serrania de Las Quinchas, in the midMagdalena river valley, Colombia. Check List, 15: 387-404.

Passamani, M.; Rylands, A.B. 2000. Feeding behavior of Geoffroy's marmoset (Callithrix geoffroyi) in an Atlantic forest fragment of south-eastern Brazil. Primates, 41: 27-38.

Peres, C.A. 1994. Diet and feeding ecology of gray woolly monkeys (Lagothrix lagotricha cana) in central Amazonia: comparisons with other atelines. International Journal of Primatology, 15: 333-370.

Rocha, R.; López-Baucells, A. 2014. Predation attempt of Hypsiboas boans (Anura: Hylidae) by Helicops angulatus (Squamata: Dipsadidae) with notes on defensive behavior. Alytes, 30: 78-81.

SEDAM. 2012. Secretaria de Estado do Desenvolvimento Ambiental, Rondônia, Brasil. Boletim climatológico de Rondônia -2010, 12: 1-34.
Stevenson, P.R.; Quinones, M.J.; Ahumada, J.A. 1994. Ecological strategies of woolly monkeys (Lagothrix lagotricha) at Tinigua National Park, Colombia. American Journal of Primatology, 32: 123-140.

Toledo, L.F.; Ribeiro, R.; Haddad, C.F. 2007. Anurans as prey: an exploratory analysis and size relationships between predators and their prey. Journal of Zoology, 271: 170-177.

Turci, L.C.B.; Bernarde, P.S. 2012. Herpetofaunistic survey in a location in the municipality of Cacoal, Rondônia, Brazil. Bioikos, 22: 101-108.

RECEIVED: 07/04/2019

ACCEPTED: $17 / 08 / 2019$

ASSOCIATE EDITOR: Paulo D. Bobrowiec 